\title{
TENDENCIES OF BIOTECHNOLOGY, INNOVATION AND DEVELOPMENT IN COLOMBIA
}

\author{
Libia Esperanza Nieto Gómez ${ }^{1}$ \\ Reinaldo Giraldo Díaz ${ }^{2}$
}

Recibido el 3 de octubre de 2014, aprobado el 2 de marzo de 2015 y actualizado el 07 de mayo de 2015

DOI: 10.17151/luaz.2015.41.19

\begin{abstract}
The role of biotechnology in the future of humanity is seen as essential and leading to address those who makes the most important challenges of economies and societies of the world in the coming decades: provision of food, water, energy, health and other resources and services for a growing population. This research article addresses from a critical stance trends in biotechnology in Colombia. It was found that the bet of the Colombian State for innovation, research and biotechnology is not at the forefront of global trends and is subject to a precarious insertion in the world market, leaving outside dimensions cultural, social and environmental. It is concluded that the State must reorient its biotechnological betting toward the construction of a sustainable society environmentally and culturally.
\end{abstract}

KEY WORDS: bioeconomy, bioethics, biotechnology, innovation, development

\section{TENDENCIAS DE LA BIOTECNOLOGÍA, LA INNOVACIÓN Y EL DESARROLLO EN COLOMBIA}

\section{RESUMEN}

El papel de la biotecnología en el futuro de la humanidad se vislumbra como fundamental y protagónico para abordar los que se suponen los desafíos más importantes de las economías y las sociedades del mundo en las próximas décadas: provisión de alimentos, agua, energía, salud y otros recursos y servicios para una población en constante crecimiento. El presente artículo de investigación aborda desde una postura crítica las tendencias de la biotecnología en Colombia. Se encontró que la apuesta del Estado colombiano por la innovación, la investigación y la biotecnología no está a la vanguardia de las tendencias mundiales y que se supedita a una precaria inserción en el mercado mundial, dejando por fuera dimensiones culturales, sociales y ambientales. Se concluye que el Estado debe reorientar sus apuestas biotecnológicas hacia la construcción de una sociedad sostenible ambiental y culturalmente.

PALABRAS CLAVE: bioeconomía, bioética, biotecnología, innovación, desarrollo 
"We cannot conceive a sustainable society which is not basedon the solar energy, the photosynthesis and the "closing the cycles" of materialsinstead of doing it on fossil fuels and mineral resources, (As the current unsustainable industrial economies). In other words: predominance of "mineral technologies" over biotechnologies, of non-organic matter based technologies over those organic life based ones, it will have been a brief pause of two centuries in the long human being history; and it would be environmentally irresponsible trying to extend this pause"

(Riechmann, 2004, p. 321).

\section{INTRODUCTION}

Colombia counts on a wide biodiversity (Carvajal \& Amaya, 2005, p. 179), being biodiversity one of the essential inputs for the development of biotechnological products, the country does not focus efforts and economical resources to science, technology and innovation production on this field yet, to achieve positioning as a point of reference in the international stage. Accordingly, in the analysis it is required to consider a complex system that includes apart from the economic, environmental, social, cultural and political setting, with synergic relations and interactions among each other, that in a long term will affect the industrial development and equity in society.

Comprehending the biotechnology perspectives worldwide and at the same time identifying the projected and attained biotechnological achievements in the country during the last decades would allow to have a global vision of biotechnological innovations environmentally sustainable to be developed in a near future, thus redirecting the policies and planning agendas at local, national and international level.

Initially, a review of international guidelines and predictions in the biotechnology field is done, proposed by organizations like OECD (Organización para la Cooperación y el Desarrollo Económicos) and Biotech (Supporting program to the development of biotechnologies in the MERCOSUR), among others. The current policies and guide lines are then reviewed and summarized, (Programa Nacional de Biotecnología del Departamento Administrativo de Ciencia, Tecnología e Innovación - Colciencias $y$ documentos CONPES). The analysis of the above information and the matching with the theories of new technologies, environmental sustainability and ethical dimensions allow to present conclusions and advise steps to follow in an institutional way in Colombia. 


\section{DEVELOPMENT}

\section{International guidelines for research, innovation and development in biotechnology}

The report by the OECD (2009). The Bio economy to 2030: Designing a policy agenda, that is the result of an interdisciplinary project of the OECD on Bio economy, gives an analysis of the three areas in which on a future biotechnology has a higher impact potential: agriculture, health and industry. It considers the evolution implications of these economy and social areas in the next decades and develops a policies agenda (OECD, 2009). The report shows the role biotechnology could play to address the challenges which are supposed to be the most important of the economies and societies in the world in the next decades: Food, water, energy, health provision besides of other resources and services for a constantly growing population (OECD, 2009; Pineda, 2014).

According to the report, laying the foundations for the establishment of biotechnology implies starting to develop an agriculture with biotechnology application to improve plants and animals variety through the access increase to technologies, widening the number of research enterprises and institutions that can use biotechnology (particularly developing countries), and promote public dialogue. In the field of health, developing regulation, investigation and medical histories systems which are able to link medical histories, prescription, genetic information and similar ones to this to support research and monitoring of the results on a long term. In the industry, increasing the support to adoption and use of internationally accepted rules for the cycle of life analysis, along with other incentives to reward the environmentally sustainable technologies (For instance, fostering research on biofuels of high-density of energy) (OECD, 2009) (Table 1). 
Table 1. Biotechnologies with high marketing probability in 2030

\begin{tabular}{|c|c|c|}
\hline Agriculture & Health & Industry \\
\hline $\begin{array}{l}\text { Widespreaduse of marker } \\
\text { assisted selection (MAS) } \\
\text { in plant, livestock, fish and } \\
\text { shellfish breeding. }\end{array}$ & $\begin{array}{l}\text { Many new pharmaceuticals } \\
\text { and vaccines, based in part } \\
\text { on biotechnological } \\
\text { knowledge, receiving } \\
\text { marketing approval each year }\end{array}$ & $\begin{array}{l}\text { Improvedenzymes for a } \\
\text { growing range of } \\
\text { applications in the } \\
\text { chemical sector }\end{array}$ \\
\hline $\begin{array}{l}\text { Genetically modified (GM) } \\
\text { varieties of major crops } \\
\text { and trees with improved } \\
\text { starch, oil, and lignin } \\
\text { content to improve } \\
\text { industrial processing and } \\
\text { conversion yields }\end{array}$ & $\begin{array}{l}\text { Greater use of } \\
\text { pharmacogenetics in clinical } \\
\text { trials and in prescribing } \\
\text { practice, with a fall in the } \\
\text { percentage of patients } \\
\text { eligible for treatment with a } \\
\text { given therapeutic }\end{array}$ & $\begin{array}{l}\text { Improved mico-organisms } \\
\text { that can produce an } \\
\text { increasing number of } \\
\text { chemical products in one } \\
\text { step, some of which build } \\
\text { on genes identified } \\
\text { through bioprospecting }\end{array}$ \\
\hline $\begin{array}{l}\text { GM plants and animals for } \\
\text { producing } \\
\text { pharmaceuticals and other } \\
\text { valuable compounds }\end{array}$ & $\begin{array}{l}\text { Improved safety and efficacy } \\
\text { of therapeutic treatments due } \\
\text { to linking pharmacogenetic } \\
\text { data, prescribing data, and } \\
\text { long-term health outcomes }\end{array}$ & $\begin{array}{l}\text { Biosensors for real-time } \\
\text { monitoring of } \\
\text { environmental pollutants } \\
\text { and biometrics for } \\
\text { identifying people }\end{array}$ \\
\hline
\end{tabular}




\begin{tabular}{|c|c|c|}
\hline $\begin{array}{l}\text { Improved varieties of } \\
\text { major food and feed crops } \\
\text { with higher yield, pest } \\
\text { resistance and stress } \\
\text { tolerance developed } \\
\text { through GM, MAS, } \\
\text { intragenics or cisgenesis. }\end{array}$ & $\begin{array}{l}\text { Extensive screening for } \\
\text { multiple genetic risks factors } \\
\text { for common diseases such } \\
\text { as arthritis where genetics is } \\
\text { a contributing cause }\end{array}$ & $\begin{array}{l}\text { High energy-desinty } \\
\text { biofuels produced from } \\
\text { sugar cane and cellulosic } \\
\text { sources of biomass }\end{array}$ \\
\hline $\begin{array}{l}\text { More diagnostics for } \\
\text { genetic traits and diseases } \\
\text { of livestock, fish and } \\
\text { shellfish }\end{array}$ & $\begin{array}{l}\text { Improved drug delivery } \\
\text { systems from convergence } \\
\text { between biotechnology and } \\
\text { nanotechnology }\end{array}$ & $\begin{array}{l}\text { Greater market share for } \\
\text { biomaterials such as } \\
\text { bioplastics, especially in } \\
\text { niche areas where they } \\
\text { provide some advantage }\end{array}$ \\
\hline $\begin{array}{l}\text { Cloning of high-value } \\
\text { animal breeding stock }\end{array}$ & $\begin{array}{l}\text { New nutraceuticals, some of } \\
\text { which will produced by MG } \\
\text { micro-organisms and others } \\
\text { from plant or marine extracts. }\end{array}$ & \\
\hline \multirow[t]{2}{*}{$\begin{array}{l}\text { Major staple crops of } \\
\text { developing countries } \\
\text { enhanced with vitamins or } \\
\text { trace nutrients, using GM } \\
\text { technology }\end{array}$} & $\begin{array}{l}\text { Low-cost genetic testing of } \\
\text { risk factors for chronic } \\
\text { diseases such as arthritis, } \\
\text { Type ll diabetes, heart } \\
\text { disease, and some cancers. }\end{array}$ & \\
\hline & $\begin{array}{l}\text { Regenerative medicine } \\
\text { providing better management } \\
\text { of diabetes and replacement } \\
\text { or repair of some types of } \\
\text { damagedtissue. }\end{array}$ & \\
\hline
\end{tabular}

Source: OECD (2009).

Supported in the definition of biotechnology of the OECD (2005), according to which biotechnology is "application of science and technology to alive organisms, alike to parts, products and models of themselves to alter alive or not alive materials aiming to produce knowledge, goods or services" (OCDE, 2005), Barrete (2009) considers its reach according to the next biotechnological techniques list:

- DNA (Deoxyribonucleic Acid)/ RNA (ribonucleic acid): Genomics, pharmacogenetics, probes of genes, genetic engineering, sequenced/synthesis/DNA-RNA Amplification/genetic expression models and antisense technology use, RNA of interference.

- Proteins and other molecules: Sequencing/synthesis/proteins and peptides engineering (including big molecules with hormonal activity), improved sending and freeing methods for big molecules with pharmacologic and proteomic action, as well as isolating and purifying of proteins, identifying of cell receptors and cell signals.

- Along with Farming, cell and tissue engineering: Cell/tissue farming, tissue engineering (including biomedical engineering and structures for tissue building), hybridizing and cell fusion, vaccinations/immunity stimuli, embryo handling. 
- Biotechnology of processes: fermentation using bioreactors, bioprocesses, bio-lixiviation, bio-production of paper pulp, biowhitening, bio desulphurization, bio filtration and bioremediation.

- Genes and vectors of DNA/RNA: Gene therapy, viral vectors.

- Bioinformatics: Building of Genome databases, proteins sequence, and complex biological processes modelling, including biology of systems.

- Nanobiotechnology: application of tools and processes of nano and micro production to the devices for studying bio systems and applications in medicine delivery, diagnosis, etc.

Barrete (2009) observes a positive general picture for the Iberoamerican biotechnology, but with very meaningful differences among the different countries. The growing of the surface planted with genetically modified organisms (OGM), of the postgraduate formation programs, of the research groups, of active researchers, of the quantity of enterprises and excellence centers, show a vigorous and dynamic field within the scientificand technological activities. For Barrete (2009), the scientific cooperation increase points out an important dynamism in the scientific field and one of the ways of complementing the equipment and technical abilities of the different research groups.

Through Biotech, supporting program to the development of biotechnologies in the MERCOSUR, which is founded in 2005 in a cooperation agreement between the European community and the MERCOSUR (Argentina, Brazil, Paraguay and Uruguay) a platform on biotechnologies is developed which is useful as instrument to promote the development and use of the applications of biotechnologies in the MERCOSUR (MERCOSUR, 2005).

MERCOSUR (2005) establishes a definition of Biotechnology (with indicators, activities, action and investment fields) which allows to statistically relate different advances and developments in biotechnology and comparing them among countries, because activities in biotechnology go through different areas that involve different disciplines, the national organisms of statistical information production in science and technology do not account for those activities adequately.

\section{Colombian policies of investigation and innovation in biotechnology}

In Colombia, the document CONPES 3582 contemplates the public action focusing on strategic areas for the prioritization of economic activities that correspond the decisions of prioritization of the scientific, technological and innovation abilities development. As starting point, identifies the following strategic areas: energy and natural resources; biotechnology; health; materials and electronics; Information and communication technologies, logistics and design, finally, building of citizenship and social inclusion (CONPES, 2009, p. 2).

The document CONPES 3582 highlights innovation as introduction to marketing, it considers "The introduction to 
marketing is what actually distinguishes an innovation and for this the politic interest in promoting the innovation to change the competitiveness of the country" (CONPES, 2009, p. 8). If the focusing on knowledge areas looks for the promotion of research on basic sciences, social sciences, education scientific studies, health, environment, sea resources, biotechnology, energy and mining, agricultural resources, industrial and of quality technologies, electronics, telecommunication and informatics (CONPES, 2009, p. 31), it is possible to understand the market widening in knowledge areas will be pursued.

One of the difficulties Colombia has and that is thought to be supplied through networking is "Scientific, technological and of innovation abilities are not distributed in an equal way in the different regions of the country" (CONPES, 2009, p. 33). To overcome the regional disparity in regards the localization of scientific and technological abilities, the document CONPES 3582 proposes the strengthening the regional abilities for the knowledge production, promotion and use. This is carried out through the establishment of regional systems of the CTel whose purpose is looking for the planning, organization improvement, implementation and assessment improvement of the CTel activities from territorial bodies (CONPES, 2009, p. 52).

A complementary strategy to the network the CONPES 3582 document complements is the promotion of "The use of information and communication technologies (ICTs) for the handwork training which is going to be carried out through the promotion of flexible and open learning environments characterized for allowing permanent access, giving the chance for team work having as main framework technologies which are grouped around a productive process. ICTs will be also integrated to the pedagogical process of doctors and students, to the improvement processes of educational institutions, in general to daily life of the scientific and academic community of the country, furthermore virtual formative programs to basic, high, and superior schools educators will be created based on methodologies that promote research. The Red Nacional Académica de Tecnología Avanzada (RENATA) is a very powerful instrument to guarantee higher coverage and partaking from the SNCTel actors, reason why its use and coverage must be promoted by means of projects that incentives its use (CONPES, 2009, p. 47).

The second strategy to strengthen research in the regions:

[...] consists on supporting research (knowledge production) in basic, high and superior educational institutions also research centers and technological development, through the economic support to the acquisition of research robust equipment and ease the fact these can be shared among the different regional actors of the national science, technology and innovation system (SNCTel) and promote alliances of consolidated research groups with emerging 
ones, aiming to close gaps of abilities in CTel among regions in the country. (CONPES, 2009, p. 53)

These guidelines are assumed in the national program of biotechnology of the administrative department of science, technology and innovation (Colciencias), which:

[...] looks forward to meeting the abilities of research and innovation of universities, research centers and enterprises with the purpose of linking one each other with the government entities to contribute to Colombia's development increase, welfare and economic competitiveness, from the biodiversity knowledge, protection and advantaging. (Colciencias, s.f. a)

The action lines of the program search for the consolidation of the biotechnological industry in Colombia, the development and production of renewable and environmentally sustainable biofuels but also knowledge, protection and sustainable advantaging of biodiversity. In accordance with the objectives and defined strategies by the national policy of science, technology and innovation, the national program of biotechnology proposes the following guidelines:

- Promoting the creation and development of business consortium and biotechnological enterprises in strategic areas.

- Incentivizing the intellectual property protection.

- Fostering legal initiatives which are for conforming a coherent and transparent regulatory frame that favors biotechnology development.

- Developing urgent regulatory initiatives needed for the startup of the national effort in biotechnology and biosecurity.

- Increasing human resources devoted to the I+D and biotechnological management in strategic areas.

- Establishing new modalities of financing for the I+D in biotechnology.

- Promoting the institutional framework for the public coordination and citizen partaking.

- Developing and display promotion tools of the biotechnological business field.

- Managing the creation of new modern biotechnological centers.

The science, technology and agricultural innovation program of Colciencias (s.f. b) is according to what is stipulated considered by the CONPES 3582 document, namely as a development and innovation source (that means, of marketing). For that, the national program of agricultural science and technology introduces elements to contextualize the agricultural situation of the world, it identifies the area trends, the agricultural structure behavior makes an approximation to the situation of the productive lines, identifies the perspectives of marketing and depending upon them, it determines the technological gaps for each chain and establishes priorities in scientific and technological development (Colciencias, 2005). 
The science, technology and agricultural innovation program beholds within its action lines, the following ones which are directly related to the biotechnology use and application:

- Biotechnology use to characterize materials and genetic features of strategic interest for genetic improvement (higher adaptability, resistance to pests and diseases).

- Bio inputs production (Bio pesticides, bio fertilizers).

- Diagnosis and treatment of diseases in the livestock sector.

- Conventional technologies for the technical improvement of farming and livestock exploitation, mechanization and input rationalization.

- Need and chance of giving higher added value (coffee, fruit and vegetables, fish, sugar cane, panela cane, cocoa, potato).

- Identification and characterization of gene features of strategic interest.

- Biotechnology for food production with high vitamin, fiber and protein content. Bio fortified.

- Biomass transformation (plastic and biodegradable textiles, biopolymer, bioethanol, biodiesel).

- The complete knowledge chain. Gene improvement, nutrition, technified production systems.

Tamayo et al. (2012) presents ageneral framework of the knowledge in biotechnology agenda creation, framed by the prospective program UN - Knowledge agenda of the research vice-rector of Nacional university of Colombia. The documents sums up the individual, group, institutional and social needs that can be presented in the biotechnology action field as well as the public policies designers who are able to find the priorities and needs in the research field within the biotechnological area in the institutional, local, regional, national and international field.

Tamayo et al. (2012) shows the world trends of biotechnology based on its color classification (Figure 1). Within the proposed cross-cutting themes collaboration nets, interdisciplinary approach and regulation policies are not included. 


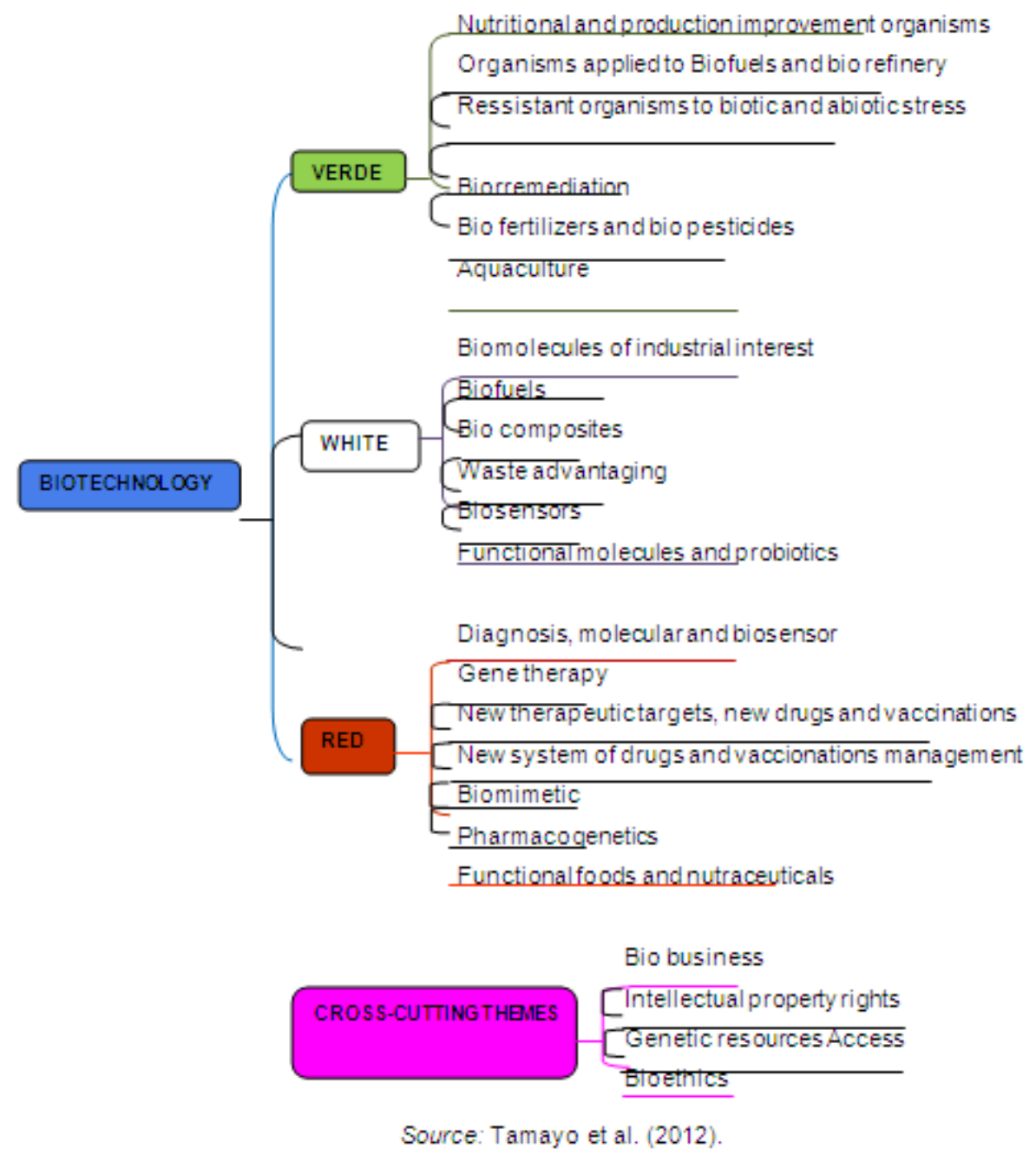

Figure 1. World trends in biotechnology applying its classification in colors.

\section{Critic analysis of biotechnology in Colombia}

In the betting within the Colombian society for biotechnology, risks and limitations must be considered "The point is not 'biotechnology yes/ biotechnology no', but what kinds of biotechnology for a sustainable society" (Reichmann, 2004, p. 321). Accordingly, Altieri (2003) supports his questioning to the green biotechnology promises, for instance, less dependence on chemical inputs, productivity increase and reduction of environmental problems, also in that biotechnology obeys the capitalist view where "reductionist science alliance with the monopolizing multinational industry takes agriculture to a wrong path" (Altieri, 2003, p. 48).

From this position, the biotechnological perspective becomes limited and only aimed towards perceiving agricultural problems as gene deficits of the urbanisms, and conceive nature as commodity, as lucky the fact biotechnology can only develop "monogenic solutions, designed on industrial models of efficiency, for derived problems from monoculture systems environmentally unstable" (Altieri, 2003, p. 48). 
The biotechnology promotion in the capitalist view context of accumulation and permanent generation of added valueleads to an unitary vision of nature which does not consider environmental and social damages: "In the critics heart there are the biotechnological effects on the social and economic conditions and the cultural, religious and ethical values" (Altieri, 2003, p. 49). In this aspect Coca, Valero \& Randazzo (2010) state that Iberoamerican societies invest their effort in a biotechnological "cloned" sector in which the policy of enterprise-university is not altered, so that, the techno-scientific system of the region favors the dependence situation even more. From this critic position it is considered that Iberoamerican societies would appeal to biotechnological devices developed by enterprises located in the center of the system and will focus on the biotechnological products implementation thrown away from other regions. If the development of the current techno-scientific system continues, the gap among countries will remain even at risk of widening.

The new geography of growth shows that by 2009 , the value of China's exports had increased more than tenfold from USD 148 billion to USD 1529 billionand the structure of its exports had changed substantially. The last 15 years have seenincreased trade in primaryresources such as energy inputs, a more than tenfold increase in the value of exports from China, and China'sincreased role as an exporter of high-end intermediates and capital goods. OECD countries' share of worldexports declined from $75 \%$ to $60 \%$ (OECD, 2011) (Figure 2).

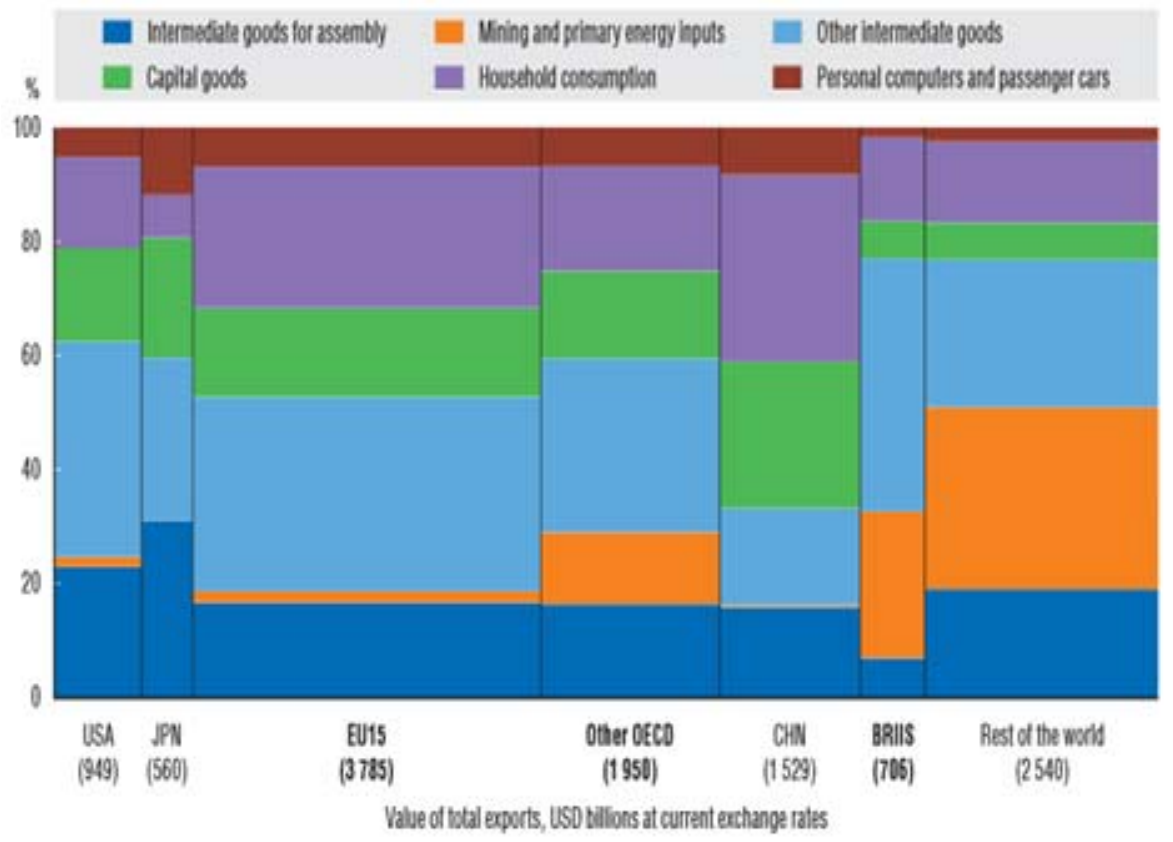

Source: OECD (2011).

Figure 2. World trade by end use, 2009. Breakdown of world exports of goods by originating region and end use, percentage 
Grupo Bioserintia (2013), taking dates of OECD (2011) shows that Colombia is far from the OECD measure in relation to the number of patents and trademarks per capita (Figure 3).

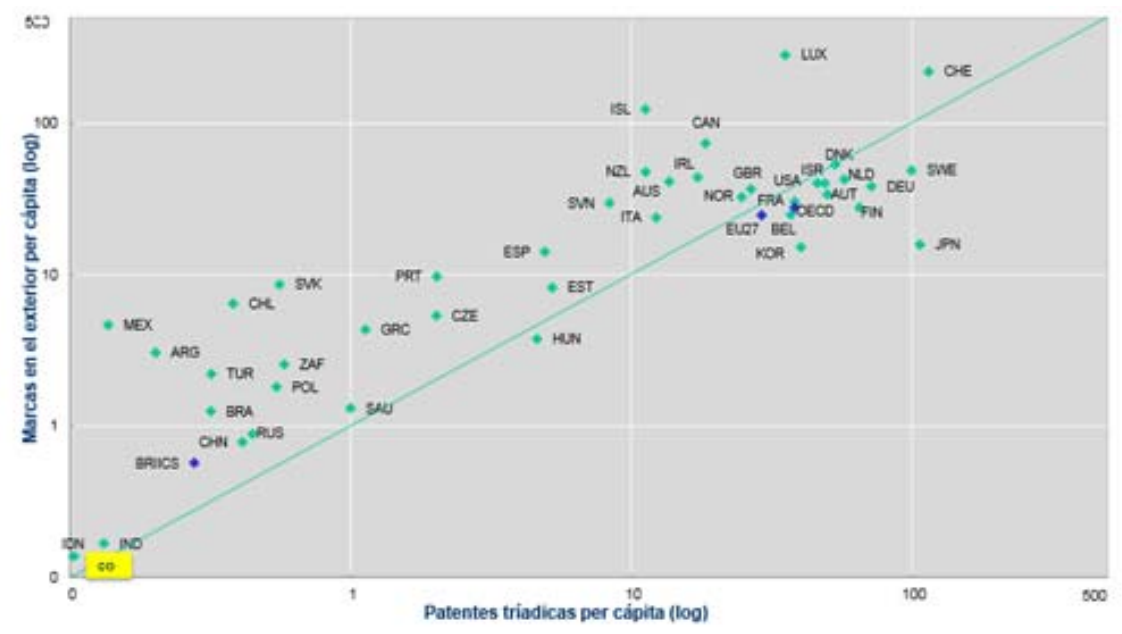

Source: Grupo Bioserintia (2013).

Figure 3. Number of patents and trademarks of Colombia per capita relative to OECD countries.

With respect to investment in research, development and innovation, Colombia is below the average for OECD countries (Grupo Bioserintia, 2013) (Figure 4).

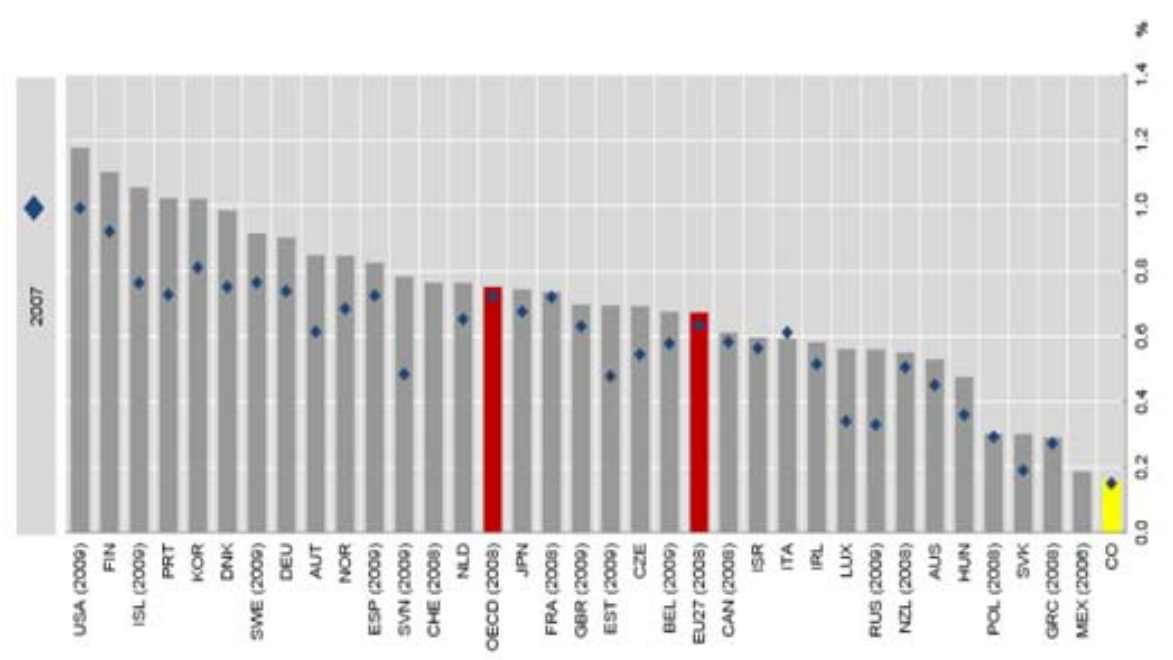

Source: Grupo Bioserintia (2013).

Figure 4. Public expenditure in Colombia in IDI with respect to OECD countries.

The number of patent applications is below 200 per year, although the trend is that increasingly patent more out of Colombia that within. In 2012, 12 PCT patents were requested. The 2012 has been 21 PCT patent applications, led by Ecopetrol with 5 and Procaps 3 (Grupo Serintia, 2013) (Figure 5). 


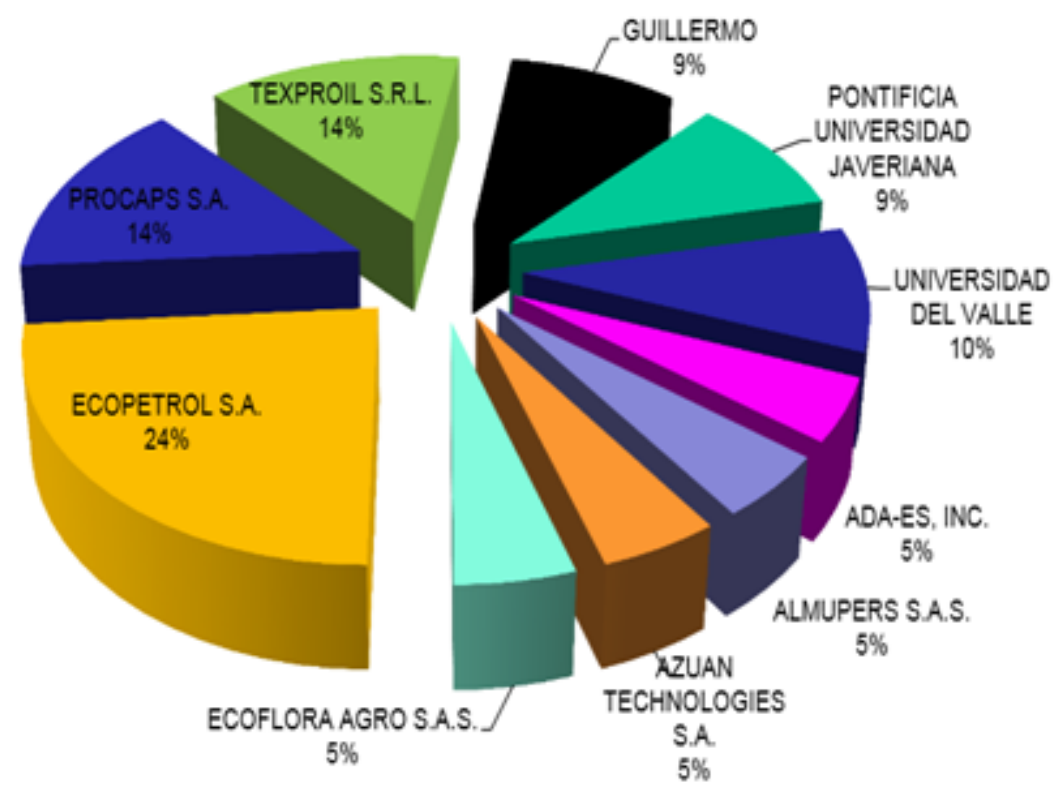

Source: Grupo Bioserintia (2013).

Figure 5. Main PCT patent applicants in 2012.

Coca et al. (2010) preview a dependence picture for the named periferic countries (or from south) and big inequality related to the biotechnological sector control. This dependence could be remedied with investments in the development areas of biotechnology emphasizing in the situated solution and specialized in problems. This coincides with the analysis of Mendez \& Rollo (2014) about the Trans-Pacific Partnership and excluded Commonwealth DevelopingCountries. Nevertheless, differences between periphery and central countries will increase unless the less biotechnologically developed regions make economic, social and educative efforts.

Riechmann (2004) considers important taking into account, for adopting gene engineering and biotechnology environmental sustainability criteria, precaution and social justice. Risks and socio-political matters associated to biotechnology exist, and they propose questions related to the objectives this looks for, benefited, the effects on living beings, environmental, social, economic and politic effects, who loses with biotechnology and whether or not exist less damaging alternatives and socially more fair (Altieri, 2003). Assuring a social and environmentally sustainable agriculture implies assessing and promoting multiple strategies that use traditional and of recent development technologies.

Riechmann (2004) asserts:

Biotechnologies - including gene engineering serving a sustainable society, if; biotechnologies to intend continuing the capitalist expansion on a new technological base (gene information 
domain and digital handling information with computers and telematics), by no means. It would be the human race suicide, towards which world potencies are strongly working nowadays. (Riechmann, 2004, p. 322)

Riechman (2004) distinguishes between traditional and modern biotechnologies. In a wide sense, the agricultural activities since the Neolithic revolution, 10.000 years ago, presuppose biotechnologies, among which plants and animals domestication (with additional techniques of gene improvement) fermentation with yeasts (bread, beer, wine, yoghurt, cheese), biofuels (alcohol, methane gas)and waste water purification with microorganisms (Riechmann, 2004, p. 90). Since the second half of the 20th century, new biotechnologies come up based, among different techniques, on the "recombinant DNA revolution", the cell fusion and new bioengineering processes (Muñoz, 1997; Riechmann, 2004). These new biotechnologies differ from the traditional ones for three reasons which are cited from Riechmann (2004), extensively quoting:

- "Bio technicians" from traditional peasant cultures could only Exchange varieties or species closely related: they could not isolate the genetic material of any organism and insert it into another. Nowadays, basically, barriers for artificial exchange of gene material between two random organisms have been torn down. Genetic manipulation goes above biologic barriers that separate the different species, puts out of fire the natural mechanisms of evolution and intervenes in the gene interactions so far unreachable for human beings...

- The recombinant DNA technology, when allowing strange genes inclusion in an organism,, it has unpredictable effects on his physiology and biochemistry: frequently harmful (among them the unleashing of cancer processes)

- Gene transferences are made by means of Vectors.

Biotechnology can be comprehended as one of the most elaborated products of modern science, as a radical breaking with this science and a new opening towards a new horizon of human action (Maldonado, 2004, p. 38). What is new about biotechnology is that it condenses the processes times that on their own would take hundreds, thousands, millions of years in accomplishing: "with biotechnology, natural times have become human times" (Maldonado, 2004, p. 38).

Biotechnology has crossings and consequences in the social, cultural, scientific, philosophical and cosmic area (Maldonado, 2004), reason why research is required and projects with complex focus and with interdisciplinary equipment that allow to address in the best way and from all possible angles ecological, environmental and productive problems of the country.

Maldonado (2004) pays special attention to scientific, ethical, and political consequences of biotechnology to illustrate the tension between bioethics and bio politics, pointing out that these three consequences are strongly related among themselves. According 
to this author, the scientific consequence of biotechnology consists on having transformed nature, having acted on nature. The ethical consequences of biotechnology have to do with the use, the access to, biotechnology; the problem consists on the discriminate use of products of scientific research, in its private appropriation. This ethical problem is revealed as a politic one. The main politic consequence of biotechnology has to do with the identification of one of the key world economy sectors, for instance: the pharmaceutics industry that contains three specific expressions of the human being existence: health, beauty and longevity. And the pharmaceutics industry is eminently private.

It was found that the bet of the Colombian government to innovate, research and biotechnology cannot keep up with the world trends and it is conditioned to a precarious insertion in the world market, leaving out cultural, social and environmental dimensions.

\section{BY WAY OF CONCLUSION}

Colombia cannot fall behind scientific and technological developments and the bio economic trends of the globalized world

Public and private investment in science and technology is not enough for the needs and challenges that in research, development and innovation in biotechnology the country faces.

It is not only necessary to widen the number of research enterprises and institutes in biotechnology, but guidelines must be taken into account, control and regulation systems to monitor the results of biotechnological studies at a long term and analyzing the scientific, ethic and politic consequences of them.

The action lines proposed by the national program of biotechnology of the national policy of science, technology and innovation of Colombia, are not connected properly to the world trends, which means it is necessary redirecting the biotechnological efforts for an environmental and culturally sustainable society construction.

\section{REFERENCES}

- Altieri, M. (2003). Dimensiones éticas de la crítica agroecológica a la biotecnología agrícola. Acta Bioethica, 1, 47-61.

- Barrete, A. (2009). La biotecnología en Iberoamérica. Situación actual y tendencias. Organización de Estados IberoamericanosAgencia Española de Cooperación Internacional. Available in http://www.oei.es/salactsi/ibero_bio_final.pdf

- Carvajal, L. y Amaya, L. (2005). Colombia e Indonesia: lejanía geográfica, cercanía temática (un ejercicio comparativo). OASIS, 
10 ,

175-192.

Available

in

http://www.redalyc.org/pdf/531/53101011.pdf

- Coca, J., Valero, J. y Randazzo, F. (2010). Gap in TechnoScientific Activity: The Iberoamerican Context. Studies in Sociology of Science, 1(2), 30-39. ISSN 1923-0176 Available in http://www.cscanada.net/index.php/sss/article/viewFilel j.sss.1923018420100102.004/1566

- Colciencias. (s.f. a). Programa Nacional de Biotecnología. Available

http://www.colciencias.gov.co/programa_estrategia/programa -nacional-de-biotecnolog-0

- Colciencias. (s.f. b). Programa Nacional de Ciencia y Tecnología Agropecuaria. Available in http://www.colciencias.gov.co/programa_estrategia/ciencia -tecnolog-e-innovaci-n-agropecuarias

- Colciencias. (2005). Programa Nacional de Ciencia y Tecnología Agropecuaria. Bases para una política de promoción de la innovación y el desarrollo tecnológico en Colombia. Bogotá: Ochoa Impresores. ISBN 958-8130-92-1. Available in http://www.colciencias.gov.co/sites/default/files/ckeditor_ files/files/Plan_Estrategico_CT_Agro_2005-2015.pdf

- CONPES (Consejo Nacional de Política Económica y Social. República de Colombia. Departamento Nacional de Planeación). (2009). Documento CONPES 3582. Política Nacional de Ciencia, Tecnología e Innovación. Bogotá, D.C., 27 de abril. Available in http://www.colciencias.gov.co/normatividad/conpes-3582-de2009

- Grupo Bioserintia. (2013). Estudio sobre el potencial de la industria biotecnológica en el país. "Diseño de Estrategia Proclúster para la configuración de una Bioregión Nacional". Entregable B. Benchmarketing de BioRegiones, Bioclusters y Políticas de Biodiversidad. Colombia, junio de 2013. Presentation available http://www.innpulsacolombia.com/sites/default/files/entregabl e

b_resumen_ejecutivo_v4_0.pdf

- Maldonado, C. E. (2004). Tensión entre la bioética y la biopolítica. A propósito de la biotecnología. In A.A.V.V. Horizontes de la bioética. Salud y realidad social (pp. 27-46). Bogotá: Academia Nacional de Medicina/Universidad El Bosque.

- MERCOSUR. (2005). Inventario diagnóstico de las biotecnologías en MERCOSUR y comparación con la Unión Europea / BIOTECH ALA-2005-017-350-C2. Manual de Indicadores de Biotecnología. Biotechsur. Available

http://docs.biotecsur.org/informes/es/inventario/1_manual_in dicadores.PDF

- Mendez Parra, Max y Rollo, Jim. (2014). The Trans-Pacific Partnership and Excluded Commonwealth Developing Countries. Trade Hot Topics, 109. Available in http://www.oecdilibrary.org/docserver/download/5jz0zb2d826b.pdf?expires=1 421160990\&id=id\&accname=guest\&checksum= 103E5A447454DE47736F9BD98EFC36C7

- Muñoz, E. (1997). Nueva biotecnología y sector agropecuario: el reto de las racionalidades contrapuestas. Instituto de Estudios Sociales Avanzados (CSIC). Documento de Trabajo 97-02. 
Available in http://digital.csic.es/bitstream/10261/2023/1/dt9702.pdf

- OECD. (2005). A Framework for Biotechnology Statistics. Paris: OECD.

- OECD. (2009). The Bioeconomy to 2030. Designing a Policy Agenda. Main Findings and Policy Conclusions. OECD International Futures Project. Available in http://www.oecd.org/futures/longtermtechnologicalsocietalchallenges/ 42837897.pdf

- OECD. (2011). OECD Science, Technology and Industry Scoreboard 2011, OECD Publishing. Available in http://dx.doi.org/10.1787/sti_scoreboard-2011-en

- Pineda, L. (2014). El algoritmo genético: ¿La "nueva" generación del desarrollo de software? Ponencia presentada en el XI Encuentro Temático Nacional realizado por RENATA en la Universidad del Cauca los días 21 y 22 de agosto.

- Riechmann, J. (2004). Transgénicos: el haz y el envés. Una perspectiva crítica. Madrid: Catarata.

- Tamayo, J. (Coord.), Chaparro, A., Ariel, C., Orrego, C., Yepes, F., Serna, L. y Ospina, S. (2012). Plan Global de Desarrollo 20102012. Prospectiva UN - Agendas de Conocimiento. Agenda: Biotecnología. Universidad Nacional de Colombia. Bogotá. Available http://www.viceinvestigacion.unal.edu.co/VRI/files/docs/ Agendas/Biotecnologia.pdf

1. Agricultural engineer Specialist in Hydraulic Resources School of Agricultural, Animal and Environmental Sciences. Universidad Nacional Abierta y a Distancia. e-mail: libia.nieto@unad.edu.co

2. Agronomist. PhD Philosophy. School of Agricultural, Animal and Environmental Sciences. Universidad Nacional Abierta y a Distancia. e-mail: reinaldo.giraldo@unad.edu.co

3. Cited author words in italics.

Para citar este artículo: Nieto Gómez, L. E. y Giraldo Díaz, R. (2015). Tendencies of biotechnology, innovation and development in Colombia. Revista Luna Azul, 41, 348-364. Recuperado de http://lunazul.ucaldas.edu.co/index.php?option=content\&tas k=view\&id=1070 